Paideusis

\title{
Deweyan Inquiry: From Education Theory to Practice (James Scott Johnston)
}

\section{David Waddington}

Volume 19, Number 2, 2010

URI: https://id.erudit.org/iderudit/1071928ar

DOI: https://doi.org/10.7202/1071928ar

See table of contents

Publisher(s)

Canadian Philosophy of Education Society

ISSN

0838-4517 (print)

1916-0348 (digital)

Explore this journal

Cite this review

Waddington, D. (2010). Review of [Deweyan Inquiry: From Education Theory to Practice (James Scott Johnston)]. Paideusis, 19(2), 113-116.

https://doi.org/10.7202/1071928ar

This document is protected by copyright law. Use of the services of Erudit (including reproduction) is subject to its terms and conditions, which can be viewed online.

https://apropos.erudit.org/en/users/policy-on-use/ 
Paideusis, Volume 19 (2010), No. 2., pp. 113-116

Review of

\title{
Deweyan Inquiry: From Education Theory to Practice.
}

\author{
by James Scott Johnston, Albany: State University of New York, 2009
}

\author{
DAVID WADDINGTON \\ Concordia University
}

As someone who sets out to teach Dewey to prospective teachers every semester, I can attest to the fact that it is not always an easy task. There are two principal reasons for this. First, Dewey tends to be difficult for the students to read; they are often not familiar with the philosophical style, and this is compounded by the fact that Dewey does not have a gift for compactness or for elegant turns of phrase. As Lewis Mumford once put it, "Mr. Dewey's pages ... take one to one's destination, but a little the worse for wear," and, indeed, there are always a few students who seem "the worse for wear" after having read Dewey (131). Second, there is a tendency on the part of students to view Dewey as an educational figure whose value is merely historical. Students are often knowledgeable about the fact that Dewey was a pioneer of child-centered education and of lifelong learning, but there is relatively little awareness of his reformist agenda or of the contemporary applications of Deweyan ideas. Thus, Dewey is often viewed as someone who once made some notable contributions to education, but who can now safely be forgotten.

It is in the context of these pedagogical challenges that we must consider James Scott Johnston's recent book, Deweyan Inquiry: From Education Theory to Practice. The aim of this short volume is to illustrate, for teachers, how Dewey's theory of inquiry is a useful, flexible tool for thinking about teaching and learning. The book is a significant success in this regard. Although there are isolated moments where the book veers into terrain that may be more interesting to philosophers of education than to teachers, Johnston's analysis opens new possibilities for thinking about teaching. Johnston is a careful and thorough scholar who understands Dewey's theory of inquiry and elucidates it effectively.

The structure of the book is clearly laid out in the introduction. In the first chapter, Johnston defines Deweyan inquiry. The following four chapters then apply this notion of inquiry to various contexts-Johnston examines, successively, science education, social science education, art education, and physical education. As was the practice in Dewey's own Democracy and Education, Johnston finishes each chapter with a helpful reprise of the key points.

Since it defines Deweyan inquiry, the first chapter of the book plays a particularly important role in Johnston's analysis. He begins by listing several general characteristics of Deweyan inquiry, of which two of the most important are as follows: 1) inquiry helps us solve and understand problems, and 2) inquiry includes what we think of as science, and although the techniques vary based on the situation, there is a common structure across contexts. Clearly, it is not difficult to see what Deweyan inquiry is in

(C) Copyright 2010. The author, David Waddington, assigns to Paideusis the right of first publication and educational and nonprofit institutions a non-exclusive license to use this document for personal use and in courses of instruction provided that the article is used in full and this copyright statement is reproduced. Any other usage is probibited without the express permission of the author. 
the general sense, but the task of filling in the "common structure" is somewhat more involved. Johnston begins this work by laying out some more specific tools of inquiry. These tools, which Johnston analyzes at some length, include taking stock of and reconstructing past solutions, utilizing techniques and theories from the context within which one is working, assembling appropriate materials, and maintaining a willingness to self-correct. One rightly gathers from this that Dewey advocates a type of open-minded, thorough, and flexible analysis.

Having outlined these techniques, Johnston then proceeds to one of the book's more difficult tasks: laying out what he refers to as the "guts of inquiry." This discussion begins simply enough: one starts with a problem, and one anticipates a solution in the form of ideas. These ideas are then tested and a solution is (hopefully) reached. However, the narrative becomes more involved when Johnston explains Dewey's distinction between two different kinds of ideas: generic propositions and conceptions. Generic propositions, in the context of inquiry, are claims about what is the case (e.g. "Johnny can't read."). Conceptions, in their simplest form, are if/then statements that provide rules (e.g. "If Johnny hasn't eaten, he can't concentrate on books.") that "license" generic propositions. Obviously, in the various contexts of inquiry, there is often a great deal of revising of both generic propositions and conceptions in order to reach a satisfactory solution to a particular problem.

Once he has laid out this basic framework for inquiry, Johnston then proceeds, in the second chapter, to apply it to science education. This is a straightforward context in which to apply Deweyan inquiry; the method of inquiry derived above has a "family resemblance" to our everyday notions of scientific method. Johnston explains that the Deweyan science teacher needs to ensure that children are tackling science problems that seem genuine to them (which is not a trivial task), and that they must become familiar with patterns of scientific inquiry. Current thinking (although perhaps not current practice) in science education has largely accepted this proposition-the idea of "discovery learning" has become popular. However, as Johnston also notes, "Dewey wants ... to ameliorate human suffering and to help solve social problems. Science education should have this as its goal, beyond the development of the habits of scientific inquiry" (36). For the most part, this element of Deweyan science inquiry has yet to be realized in the school system.

Having dealt with science education, Johnston expands his analysis to education in the social sciences. Dewey was a strong proponent of the social sciences- he had great faith in the capacity of the human sciences (including, of course, educational research), to address social problems. There are, however, some difficulties, which crop up when applying this framework to education. Johnston notes that activities in science education, when competently conducted, are often hands-on. Social science education sometimes provides an unfortunate contrast case. Johnston remarks: "Too often ... social sciences such as geography and history are taught from a textbook or other resource at one remove from an existential situation when active experimentation should be undertaken" (47). The social sciences cannot be taught as though they were "dead knowledge"-students need to be brought into contact with live questions. History, for example, can be viewed as a record of how groups of humans grapple with problems, and these difficulties can be revived and posed to the students. More than 100 years ago, the teachers at the Dewey School encouraged students to pursue this kind of inquiry. Especially with the help of tools like film and computer simulation that facilitate its conduct, Deweyan inquiry in the social sciences offers a lot of interesting classroom possibilities.

In the fourth chapter, Johnston examines Deweyan inquiry in the "seemingly odd" context of art and art education. Art does not seem like such an odd context for Deweyan inquiry when one considers that Dewey was an influential theorist in this domain, having published Art as Experience in 1934. Nevertheless, the basic framework of inquiry does not transfer as straightforwardly to art as it does to the sciences and the social sciences. The nature of the "problem" is certainly somewhat different: the artist starts with an emotional idea of some kind which needs to be worked out. This idea is then worked out through a continuous process of imaginative inquiry and experimentation using various possible materials (e.g. words, building materials, paint). Through the products of art, the original situation is somehow addressed. Notably, this notion of artistic inquiry has important implications for 
art education: it underscores the importance of students expressing themselves (i.e. resolving a genuine artistic impulse) rather than simply learning artistic techniques, and it also highlights the importance of allowing students the room to experiment artistically.

In the final chapter of the book, Johnston addresses inquiry "as an affair of body" (71). This is the most speculative chapter of the book since, as Johnston notes, "Dewey does not specifically address bodily kinesthetic education" (74). Johnston's application of the inquiry framework here focuses on contexts like sports, dance, and theatre in which deliberate control of movement is especially important. In a sport like hockey, for example, one has to learn to stick-handle a puck, and one conducts a certain amount of experimentation in order to figure out how to coordinate things properly. Invoking Dewey's discussion of the reflex arc, Johnston comments, "the focus is on tight synchrony between mind and body. Thought, sensation, and movement are inextricably linked together" (74). By highlighting this form of inquiry as important, Johnston hopes (among other things) to bolster the legitimacy of physical education programs.

The summary offered here does not do full justice to Johnston's analyses, which are consistently clear, concise and useful. Johnston has a capacious knowledge of the Deweyan corpus, and he is able to draw judiciously from various texts in order to buttress his account. As a result, any of the first four chapters could play a useful role in a teacher education class or perhaps a graduate course on Dewey. Given the fact that Johnston addresses a number of specific educational contexts, the book should also prove particularly helpful to teachers who are subject specialists.

However, although Johnston has largely succeeded in his aim of outlining Deweyan inquiry, there are a few points at which I suspect there may be a "missed connection" with his intended audience of teachers. In particular, I am thinking of Johnston's discussion of induction and deduction in the science education chapter as well as the summary of the "guts" of Deweyan inquiry. Although these discussions are worthwhile (particularly in the latter case), they may be of more interest to philosophers than to teachers.

Another minor issue is that the chapter on bodily kinesthetic education seems somewhat less convincing than the others and has fewer insights to offer in terms of educational practice. Part of the reason for this is simply that Johnston has little material on which to draw. Although he notes that Dewey had some interest in the Alexander technique, an alternative medicine practice that emphasized bodily awareness, the fact remains that Dewey was largely silent on the topic of bodily inquiry. In addition to this difficulty, one gets a sense that bodily inquiry may involve less reflection than the other types of inquiry. Consider the following example: as a downhill skier, I am currently improving my skill at skiing amongst the trees. Clearly, this requires a certain amount of tool use (the skis), as well as a degree of bodily coordination. There is also some experimentation that takes place, and failed experiments impact the process in both a literal and a figurative sense. However, an excess of thinking, at least in the case of skiing through the trees, often seems to bring the "inquiry", as it were, to an abrupt conclusion. In other words, there is a degree of automatization that prevails in these activities (and perhaps must prevail) that may not prevail in other kinds of inquiry. This does not necessarily compromise the notion of bodily inquiry, but it does highlight the fact that there may be some interesting unresolved questions here.

One final criticism that could be raised is that Johnston might have said more about new approaches to science and technology education. Since the 1980s, a vigorous movement has arisen amongst scholars in science education that emphasizes critical examination of the links between science, technology, society, and the environment (STSE). Issues like food production and global warming fit nicely under the STSE banner, and this approach to education is quite congruent with Dewey's emphasis on helping students understand the role that science and technology play in society. In addition, STSE promises to interest a wider range of students in science education by helping them see science and technology as posing genuine and pressing problems for them. Johnston acknowledges the importance of this; he comments, "The greater impediment to successful scientific inquiry ... is a failure ... to create the institutional and classroom contexts in which scientific inquiry can take hold" 
(39). The expansive scope and concern for socio-scientific issues offered by the STSE movement renders it one of the best prospects of renewing Deweyan ideals in public education.

Despite the fact that there are some minor criticisms that can be applied to Johnston's account, these are vastly outweighed by the merits of the analysis. His lucid account reminds readers of the original promise of Dewey's early writings: a system of education, spanning a variety of domains that would create thoughtful, critical, and capable citizens. Indisputably, inquiry lies at the heart of this system. By clarifying this, Johnston offers teachers the chance to get "back to basics" in a progressive sense, to return to some of the valuable but often forgotten insights that initially nourished the progressive education movement.

\section{References}

Dewey, John. Art as Experience. New York: Minton, Balch \& Company, 1934.

Johnston, James Scott. Deweyan Inquiry: From Education Theory to Practice. Albany: SUNY Press, 2009. Mumford, Lewis. The Golden Day. New York: Beacon Press, 1957. 